\title{
Interesting Incidents with Sphex pensylvanicus Linnaeus, 1763 (Hymenoptera: Sphecidae) Wasps and Their Prey Items in Sioux City, Iowa, $\mathrm{USA}^{1}$
}

\author{
G. K. Lechner ${ }^{2}$
}

\begin{abstract}
The behavior of Sphex pensylvanicus wasps was observed in the presence of live potential prey items (katydids) under artificial conditions in Sioux City, Iowa, USA. When a prey item was not attacked (17 out of 20 instances) wasps engaged in what looks like "displacement preening" of her antennae using her legs. In the three instances when stinging behavior was noted, the katydid appeared to have been stung ventrally behind the head. One of the three instances is suggestive of a prey item favored over another.
\end{abstract}

Key Words: Sphex pensylvanicus, Hymenoptera, Sphecidae, displacement preening, prey choice, Sioux City, Iowa

Sphex Linnaeus is a genus of moderate to large solitary fossorial wasps with a worldwide distribution. The females hunt ensiferan orthopterans, primarily katydids (Tettigoniidae), although crickets (Gryllacridae and Gryllidae) are occasionally used. These prey items, which sometimes are larger than the wasps, are paralyzed - not killed - by stinging and then stored in underground cells to serve as food for the wasp larvae (Bohart and Menke 1976). Seven species of Sphex are found in the United States; most are of only regional distribution. However, S. pensylvanicus and its smaller congener, S. ichneumoneus, are widespread, covering most of the continental United States and portions of southern Canada (Bohart and Menke 1963, Buck 2004).

Sphex pensylvanicus wasps are reported to feed on honeydew and nectar (Kurczewski 1997). The following species of katydid (Orthoptera: Tettigoniidae) have been reported as prey items taken by S. pensylvanicus females to provision their larvae: Stilpnochlora laurifolia (Linnaeus, 1758) [Reinhard 1929, as Microcentrum laurifolium (Linnaeus, 1758)], Scudderia furcata Brunner von Wattenwyl, 1878 (Reinhard, 1929; Frisch 1938; and Rau 1944, the latter as Phaneroptera furcata), Microcentrum rhombifolium (Saussure, 1859) (Frisch 1938); Microcentrum retinerve (Burmeister, 1838) (Krombein 1955, Rigley and Hayes 1977), Microcentrum spp. and Phaneroptera spp. (Bohart and Menke 1976), Scudderia septentrionalis

\footnotetext{
${ }^{1}$ Submitted on April 25, 2016. Accepted on April 28, 2016. Last revisions received on May 11, 2016.

${ }^{2}$ Sioux City, Iowa, USA. E-mail: lechnerg_wcqma@yahoo.com
}

DOI: 10.9784/LEB4(1)Lechner.01

Electronically available on May 31 2016. Mailed on May 31, 2016. 
(Serville, 1838) (Kurczewski 1997), as well as Scudderia, Pterophylla, and Neoconocephalus spp. (Brockmann 1985). As much as possible, katydid names used in this paper have been updated using the search function in the database Orthoptera Species File Online (Eades et al., no date) http://orthoptera.speciesfile.org/HomePage/Orthoptera/HomePage.aspx .

Every summer since 2003, I have been observing a nesting aggregation of $S$. pensylvanicus that has been entering apertures in a vertical concrete block retaining wall on a residential lot in Sioux City, Iowa. The females nest in the soil behind the blocks. At this nesting site, katydid prey species that I have taken from female $S$. pensylvanicus include: Scudderia furcata (Figure 1), Scudderia curvicauda (De Geer, 1773), Microcentrum rhombifolium (Figure 2), Neoconocephalus nebrascensis (L. Bruner, 1891) (Figure 3), and Amblycorypha oblongifolia (De Geer, 1773) (Figure 4). The most frequently encountered prey item is $S$. furcata. The hunting grounds for the wasps in this aggregation are unknown.

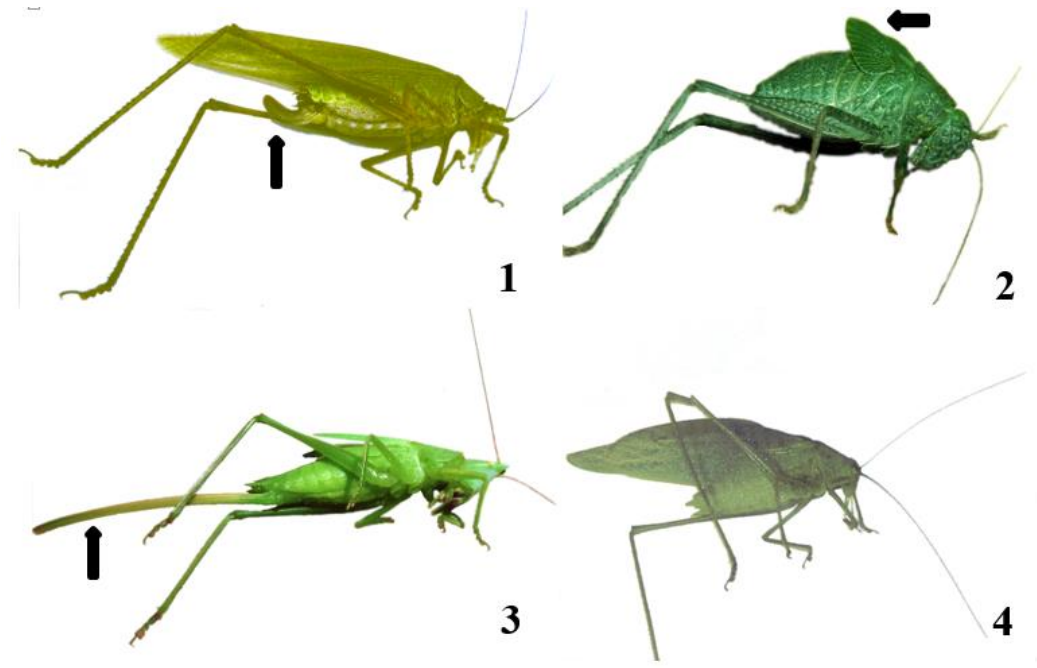

Figures 1-4. Katydid (Orthoptera: Tettigoniidae) prey species taken by the author from the predator, female Sphex pensylvanicus wasps from 2009-2013. 1. Scudderia furcata Brunner von Wattenwyl, 1878 adult female (arrow points to ovipositor). This is the most commonly seen prey item hunted by $S$. pensylvanicus. 2 . Microcentrum rhombifolium (Saussure, 1859) male, last instar nymph (note reduced wings, arrow). 3. Neoconocephalus nebrascensis (L. Bruner, 1891) last instar female, arrow points to ovipositor. 4. Amblycorypha oblongifolia (De Geer, 1773) adult male.

In 2009, I found a site, located approximately 4.8 road kilometers (approximately 3 miles) southwest of the $S$. pensylvanicus nesting site, where I easily caught katydids. I do not know the relative abundances of the 
species of katydid at this locality. With those lively, potential prey items available, I offered them to a $S$. pensylvanicus wasp from time to time under artificial conditions.

I used a clear plastic empty peanut butter jar (capacity, 1 pound or approximately 454 grams) or a glass jar of similar size. A jar holding a captured wasp would be inverted mouth-to-mouth over a jar holding a katydid. The wasp and katydid would eventually find their way into the same jar, and I would secure the lid. I turned the jar gently on occasion to ensure that the wasp would contact the prey. In total, there were 20 instances where a wasp was offered one or more katydids.

For the most part, the katydids were not very active but would jump occasionally. The wasps, however, were quite energetic. Those which failed to show any interest in the potential prey invariably exhibited two types of behavior usually alternating between them. The first consisted of flying rapidly against the side of the jar as if trying to escape. When a wasp ceased this flying mode, she would stand relatively still but would perform grooming activities consisting of rapidly running her forelegs through her mouthparts or combing her antennae, either alternately or concurrently, by using the antennal combs located on her forelegs. Also, the grooming $S$. pensylvanicus wasp would flex her gaster strongly from side to side brushing it with her hind legs (Figure 5). Evans (1966) stated that grooming behavior by solitary wasps occurs periodically especially after feeding, mating, prey carriage or emergence from the burrow. He stated further, "Grooming may also occur when the wasp is prevented from completing certain phases of its behavior or in cases of conflicting drives" ... "such grooming is suggestive of displacement preening in birds."

However, there were three occasions in 2009 when a wasp attacked and stung an offered katydid. The first occurred on September 5, when a wasp was presented with an adult Scudderia furcata female. At first, the female $S$. pensylvanicus wasp did not seem interested in the prey. However, after about fifteen seconds, the wasp and katydid tumbled together. The wasp was somewhat venter to dorsum and head to abdomen to the katydid. The wasp had the tip of her abdomen positioned ventrally and posteriorly to the head of the katydid. Presumably, this was the stinging procedure because the katydid appeared to be completely paralyzed. While the wasp and katydid were thus engaged, I dumped them from the jar to the table top for better observation (Figure 6). After stinging the prey item, the wasp began carrying the katydid in the usual manner, straddling the prey and grasping the katydid's antennae with her mandibles (Figure 7). Upon reaching the edge of the table, the wasp flew with her prey and landed in the lawn (Figure 8).

Sphex pensylvanicus captures different species of katydids. A second stinging episode that took place on September 9 is noteworthy in this 
regard. A wasp was offered a common meadow katydid, Orchelimum vulgare T. W. Harris, 1841, in a jar. While confined in this jar with a potential prey for about two minutes, the wasp showed no apparent interest. This wasp was then put into a jar with a Scudderia furcata. For about 30 seconds the wasp also seemed indifferent to this prey, but then she attacked and stung. I noted that this wasp was also stinging the katydid ventrally behind the head as I saw in the previously described stinging episode. After stinging the katydid, the wasp began walking on the table top and carrying her paralyzed prey very briefly before she took flight upward and eastward with her katydid, and I lost sight of them.

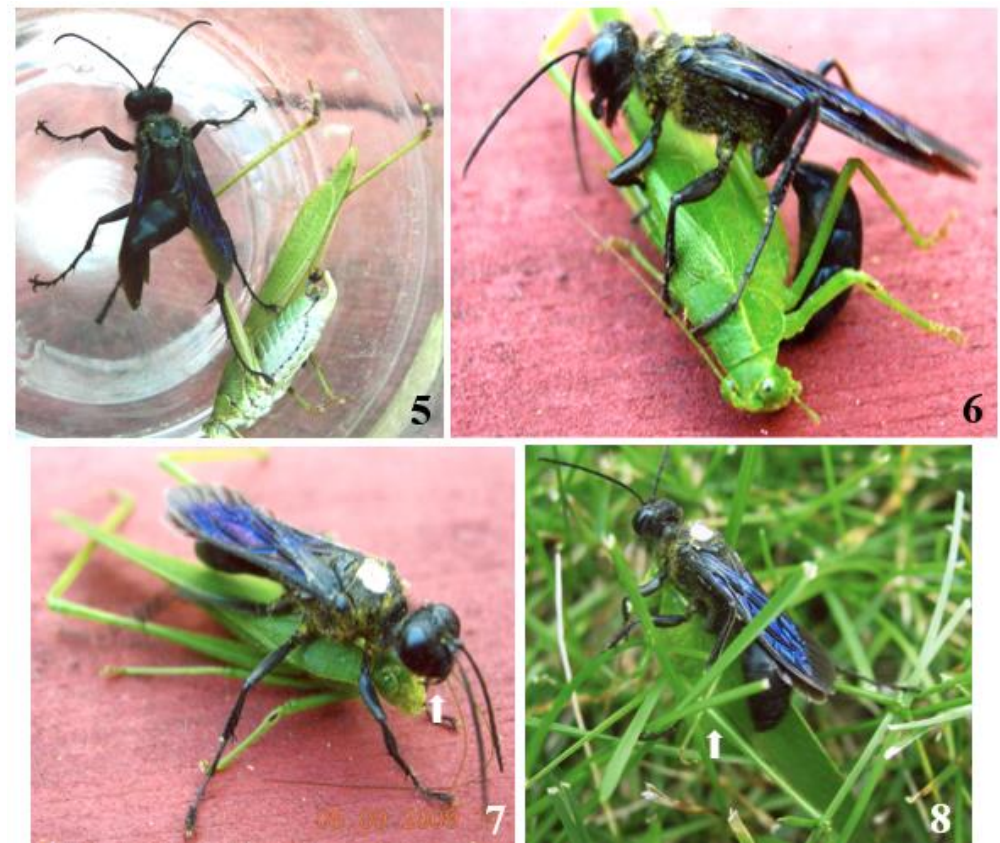

Figures 5-8. Female Sphex pensylvanicus prey paralyzing behaviors. For comparison, female $S$. pensylvanicus are approximately $25-34 \mathrm{~mm}$ long (Frisch 1938). 5. Grooming wasp flexing her gaster and brushing it with her hind legs next to Scudderia furcata katydid paralyzed prey. 6. Sphex pensylvanicus wasp with tip of her abdomen positioned ventrally and posteriorly to the head of S. furcata katydid. Katydid appears to be completely paralyzed. 7. Wasp carrying $S$. furcata by straddling it and grasping the katydid's antennae (arrow). 8. Wasp still holding to her paralyzed prey (arrow), Scudderia furcata katydid, after having flown to lawn approximately 3-4 $\mathrm{m}$. Note the similarity in coloration between the katydid and the green grass.

The third episode happened on September 14 when I placed an $S$. pensylvanicus into a jar with a male Scudderia furcata. For about 30 
seconds, the wasp showed no apparent interest in the katydid, but then she straddled the prey and began the stinging procedure. At this point, I dumped them out onto the table top. Perhaps this startled the wasp since she immediately ceased stinging and flew away.

Did the refusal to attack a smaller prey, O. vulgare (second incident) but her acceptance of an $S$. furcata, indicate a possible prey preference? Brockmann (1985) reported that the Great Golden Digger Wasp, Sphex ichneumoneus (Linnaeus, 1758), has no aversion to using several species of Orchelimum as prey as well as many other genera of katydids and tree crickets. Prey size and other environmental factors, such as predator satiation, could be contributing to the wasps' feeding choices as are prey's relative abundance, and genetically-based preferences in the wasps.

\section{Acknowledgments}

I thank Dr. Thomas J. Walker of the University of Florida in Gainesville, Florida, for his kind assistance in identifying katydids. The katydids shown in Figures 1-4 were donated to the Ensiferan Collection at the University of Florida. Four anonymous colleagues reviewed the paper and offered numerous constructive suggestions. My wholehearted thanks to all.

\section{Literature Cited}

Bohart, R. M. and A. S. Menke. 1963. A reclassification of the Sphecinae with a revision of the Nearctic species of the tribes Sceliphronini and Sphecini (Hymenoptera, Sphecidae). University of California Publications in Entomology 30:91-182.

Bohart, R. M. and A. S. Menke. 1976. Sphecid Wasps of the World: A Generic Revision. University of California Press. Berkeley, California, USA. 696 pp.

Brockmann, H. J. 1985. Provisioning behavior of the Great Golden Digger Wasp, Sphex ichneumoneus (L.) (Sphecidae). Journal of the Kansas Entomological Society 58:631655.

Buck, M. 2004. An annotated checklist of the spheciform wasps of Ontario (Hymenoptera: Ampulicidae, Sphecidae and Crabronidae). Journal of the Entomological Society of Ontario 134:19-83.

Eades, D. C., D. Otte, M. M. Cigliano, and H. Braun. (No date) Orthoptera Species File. Version 5.0/5.0. [May 11, 2016]. http://Orthoptera.SpeciesFile.org

Evans, H. E. 1966. The behavior patterns of solitary wasps. Annual Review of Entomology 11:123-154. http://dx.doi.org/10.1146/annurev.en.11.010166.001011

Frisch, J. A. 1938. The life-history and habits of the Digger Wasp, Ammobia pennsylvanica (Linn.). The American Midlands Naturalist 19:673-677. http://dx.doi.org/10.2307/2420481

Krombein, K. V. 1955. Miscellaneous prey records of solitary wasps. I. (Hymenoptera: Aculeata). Bulletin of the Brooklyn Entomological Society 50:13-17.

Kurczewski, F. E. 1997. Activity patterns in a nesting aggregation of Sphex pensylvanicus L. (Hymenoptera: Sphecidae). Journal of Hymenoptera Research 6:231-242

Rau, P. 1944. The nesting habits of the wasp, Chlorion (Ammobia) pennsylvanicum L. Annals of the Entomological Society of America 37: 439-440. http://dx.doi.org/10.1093/aesa/37.4.439

Reinhard, E. G. 1929. The Witchery of Wasps. The Century Company. New York, NY, USA. $291 \mathrm{pp}$.

Rigley, L. and H. Hays. 1977. Field observations including acoustic behavior of the BlackDigger Wasp, Sphex pennsylvanicus (Linn.). Proceedings of the Pennsylvania Academy of Science 51:32-34. 